\title{
Emlörákok TNM-8 szerinti anatómiai és prognosztikai stádiumainak retrospektív vizsgálata elhunyt, valaha emlőrákos betegek adatai alapján
}

\author{
Zombori Tamás dr. ${ }^{1}$ - Lehóczky Luca ${ }^{1}$. Cserni Bálint ${ }^{2}$ \\ Nyári Tibor ${ }^{3}$ - Cserni Gábor dr. ${ }^{1,4}$ \\ Szegedi Tudományegyetem, 'Általános Orvostudományi Kar, Patológiai Intézet, \\ ${ }^{2}$ Természettudományi és Informatikai Kar, Informatikai Intézet, Szoftverfejlesztés Tanszék, \\ ${ }^{3}$ Általános Orvostudományi Kar, Orvosi Fizikai és Orvosi Informatikai Intézet, Szeged \\ ${ }^{4}$ Bács-Kiskun Megyei Oktató Kórház, Kecskemét
}

Bevezetés: A tumor-nodus-metastasis (TNM) alapú stádiumbesorolás új, nyolcadik változata a hagyományos T, N és M kategóriákon alapuló anatómiai stádium mellett egy biomarkereket figyelembe vevő prognosztikai stádiumot is definiált emlőrákban.

Célkitüzés: A nyolcadik stádiumbesorolásban figyelembe vett prognosztikus változók, valamint az anatómiai és prognosztikai stádiumok megoszlásának vizsgálata elhunyt, de korábban emlőrákkal diagnosztizált beteganyagban a teljes túlélés alapján.

Módszer: Retrospektív vizsgálatunkba a 2010 és 2015 között a Bács-Kiskun Megyei Kórházban mútött, reszekciós mintából kórismézett, dokumentált okok miatt elhunyt emlörákos betegeket vontuk be. A prognosztikus markerek adatait a betegek kórszövettani leleteiból nyertük. Statisztikai modelljeink az egyutas ANOVA, a Dunn-féle post hoc teszt, valamint a Kaplan-Meier-analízis voltak.

Eredmények: 303 beteg adatait vizsgálva a legtöbb prognosztikus tényezőben, így az anatómiai és prognosztikai stádiumok vonatkozásában is, szignifikáns különbséget találtunk a tumoros halálozás $(\mathrm{n}=168)$ és a nem tumoros halálozás ( $\mathrm{n}=135)$ csoportja között. Ugyancsak szignifikáns különbségeket tudtunk kimutatni egyes pT- és pN-kategóriák, gradusok, ösztrogénreceptor-státuszok között az ötéves teljes túlélés alapján. Vizsgálatunk eredményei szerint az I. és II. stádium kivételével, valamennyi további anatómiai és prognosztikai stádium különbözik a többitől túlélés tekintetében $(\mathrm{p}<0,001)$. Kiemelendő, hogy az egységes IV. stádiumú betegségben is adódott túlélésbeli különbség az ösztrogénreceptor-, progeszteronreceptor- és HER2-státuszok alapján determinált betegcsoportok között: a tripla negatív és ösztrogénreceptor-pozitív, HER2-negatív tumorok túlélése ebben a stádiumban is különbözött.

Következtetések: Valós túlélési adatokon alapuló elemzésünk szerint az újszerú prognosztikai stádiumok a korábbi anatómiai stádiumokhoz hasonlóan elkülönítik a betegeket teljes túlélésük szerint. Eredményeink validálják az új prognosztikai stádiumbesorolást, de előre is mutatnak a jelenleg egységes IV. stádium tagolása irányában. Orv Hetil. 2017; 158(35): 1373-1381.

Kulcsszavak: emlőrák, prognosztikai stádium, teljes túlélés, TNM-stádium

\section{Evaluation of anatomic and prognostic stages of breast cancer according to the 8th edition of the TNM staging system - Retrospective analysis based on data from deceased patients once diagnosed with breast cancer}

Introduction: The 8th edition of the Tumor-Node-Metastasis (TNM) based staging of breast cancer introduces a prognostic stage influenced by biomarkers along the traditional $\mathrm{T}, \mathrm{N}$ and $\mathrm{M}$ categories.

Aim: To retrospectively assess stage influencing prognostic variables; and the anatomic and prognostic stages on the basis of the overall survival (OS) of a cohort of deceased patients once diagnosed with breast cancer.

Method: We included patients with known causes of death certified at the Bács-Kiskun County Teaching Hospital and having a history of breast cancer diagnosed on a resection specimen at the same institution. Prognostic factors were 
obtained from the histopathological reports. Statistics included one-way ANOVA, Dunn's post hoc test and KaplanMeier curve analyses.

Results: The 303 patients grouped as breast cancer related death $(\mathrm{n}=168)$ or unrelated $(\mathrm{n}=135)$ showed significant differences in most stage defining prognostic factors and the anatomic and prognostic stages. Significant differences in 5-year OS were observed between $\mathrm{pT}$ and $\mathrm{pN}$ categories, histological grades and estrogen receptor statuses. Except for stages I and II, significant differences were found between both different anatomic and prognostic stages $(\mathrm{p}<0.001)$. Stage IV is by definition uniform, but we identified survival differences between biomarker based subgroups: triple negative carcinomas had worse OS than estrogen receptor positive and HER2 negative carcinomas. Conclusions: Our analysis based on real survival data suggests that the prognostic stages separate patients according to OS similarly to the anatomic stages. The results validate the prognostic stages, but also suggest that separating stage IV disease according to biomarkers makes sense.

Keywords: breast cancer, overall survival, prognostic stage, TNM staging

Zombori T, Lehóczky L, Cserni B, Nyári T, Cserni G. [Evaluation of anatomic and prognostic stages of breast cancer according to the 8 th edition of the TNM staging system - Retrospective analysis based on data from deceased patients once diagnosed with breast cancer]. Orv Hetil. 2017; 158(35): 1373-1381.

(Beérkezett: 2017. július 10.; elfogadva: 2017. augusztus 7.)

\section{Rövidítések}

AJCC $=$ American Joint Committee on Cancer; DOD $=$ dead of disease (betegség progressziója miatti halálozás); DOOC = dead of other causes (a daganatos alapbetegségtól független halálozás); DWD = dead with disease (az emlőrák igazolt lokális, regionális vagy távoli kiújulása mellett a halál oka a daganattól független); ER = ösztrogénreceptor; HER2 = humán epidermalis növekedési faktor receptor-2; HG/LER = high grade vagy low estrogen receptor pozitív esetek; LG-PR = low grade és progesteron receptor pozitív esetek; ODX = Oncotype Dx; ODX-Hsz: Oncotype Dx helyettesítő szabály; ODX-RS = Oncotype Dx recurrence score; OS = teljes túlélés; PR = progeszteronreceptor; TNM = Tumor-Nodus-Metastasis; UICC = Union for International Cancer Control/Union Internationale Contre le Cancer

A malignus daganatok prognózisát számos tényező befolyásolja, és ezek között kiemelkedő szerepe van a tumorok stádiumának. A stádium hagyományosan a daganat anatómiai kiterjedését, a szervezetben lévő tumormennyiséget (tumour burden) tükrözi. Legelterjedtebb rendszere a múlt század elején Pierre Denoix által megfogalmazott tumor-nodus-metastasis (TNM-) rendszer, amely folyamatos változásokon megy keresztül az ismeretanyag bővülésének tükrében [1]. Napjainkban alkalmazásának két fó forrása az American Joint Committee on Cancer (AJCC), illetve az Union for International Cancer Control/Union Internationale Contre le Cancer (UICC) által kiadott, méretében egyre nagyobb két könyv [2,3], amelyeknek 2016 végére a nyolcadik kiadása készült el. A TNM-alapú staging sokat vitatott hibája, hogy az alapján meghatározott stádiumok, azaz a daganat kiterjedése nem tükrözi a tumor biológiai viselkedését. Azonos stádiumba tartozó tumorok, egyéb prog- nosztikus faktorok alapján, teljesen másképp viselkedhetnek, és ez csökkenti a stádium prognosztikus összehasonlításokban betöltött szerepét. Például egy azonos méretű, nyirokcsomó-státuszú, távoli áttétektől mentes, tehát azonos TNM-besorolású ösztrogénreceptor- (ER-) pozitív és negatív emlőrák merőben eltérő módon viselkedhet, és viselkedését egyéb prognosztikus tényezők, például a tumor differenciáltsága (grade, gradus) is befolyásolhatja. Ugyancsak igaz az is, hogy azonos gradus és receptorstátusz mellett a nagyobb $\mathrm{T}, \mathrm{N}$ vagy $M$ kategóriák esetén rosszabb prognózis várható.

A korábban az Orvosi Hetilapban is ismertetett hatodik kiadású TNM emlőrákra vonatkozó elemeit [4] a hetedik kiadás alig módosította. Ezzel szemben a 2018. januártól használandó nyolcadik kiadás [5] elrugaszkodott a stádiummeghatározás hagyományos, kizárólag $\mathrm{T}$, N és M kategóriák alapján történő besorolásától; a grade mellett az ER, a progeszteronreceptor (PR), a humán epidermalis növekedési faktor receptor-2 (HER2-) státusz, valamint génexpressziós vizsgálaton alapuló, tumorkiújulást jósló pontszám is szerepet kapott a stádiumok újszerû kialakításában. Más daganatoknál már korábban is érvényesültek egyéb, stádiumot meghatározó paraméterek, de az emlőrákok esetén kellő mennyiségú és minőségü adat csak a nyolcadik kiadásra gyuult öszsze, hogy ezt lehetővé tegye [2].

A differenciációt tükröző gradus volt a legkorábbi prognosztikus marker, amelynek standardizálását a nottinghami munkacsoport végezte el $[6,7]$. A további biomarkerek prognosztikus szerepének vizsgálatai jellemzően retrospektívek, és nem rendelkeznek kezelésmentes kontrollcsoporttal. Nagy, utánkövetéses adatbázisok korábban nem álltak rendelkezésre, mivel például a HER2státuszt 2010-ig nem regisztrálták az Egyesült Államok- 
ban. A biomarkereket is figyelembe vevő prognosztikai stádium kialakításában részben publikált, részben még nem közölt vizsgálatok játszottak szerepet [8-10]. Ezen eredményekre alapozva, a nyolcadik kiadásban a prognosztikai stádiumokban megvalósul az „upstaging”. A tripla negatív (ER-, PR- és HER2-negatív) emlőrákok, függetlenül a gradustól, a rosszabb prognózis miatt előrehaladottabb stádiumba kerülnek, illetve ehhez hasonlóan a magas gradusú, HER2-negatív, hormonreceptorpozitív esetek, a kedvezőtlen kórjóslat miatt, szintén magasabb stádiumba sorolandók, a T, N és $\mathrm{M}$ alapján kialakított anatómiai stádiumhoz képest.

A prognosztikai stádium további opcionális kategóriája a génexpressziósprofil-alapú vizsgálat, amelynek célja a kiújulás jóslása. A szakirodalom szerint ez ideig a 21 gén vizsgálatán alapuló Oncotype Dx (ODX) recurrence score (RS) rendelkezik a legmagasabb evidenciaszinttel az ER-pozitív, HER2-negatív (és általában pN0) tumorok körében. A hasonló genomikai tesztek hatása leginkább abban mutatkozhat, hogy segítenek azonosítani azon T2N0M0-ás eseteket, amelyeknek alacsony a kiújulási rizikójuk, és így a II. stádiumból az I. stádiumba átsorolhatók („downstaging”). Az ODX-szel folytatott eddigi vizsgálatok alapján „upstaging” ajánlás még nem született. Ugyanakkor az ODX-et magasnak tartott ára és limitált finanszírozása miatt Magyarországon nem alkalmazzák széles körben. Számos alternatívával próbálkoztak, amelyek egyike sem ad pontosan azonos eredményt, de a hétköznapokban néha pontatlanabb alternatívákat is megfelelőnek fogadnak el, ha lényegesen olcsóbbak. Gage és mtsai egy olyan szabályt közöltek, amely szerint a jól differenciált (alacsony gradusú) és PR-pozitív emlőrákok (LG-PR) az $\mathrm{RS}<11$ csoportba tartoznak (ez az új stagingrendszerben a „downstaging” feltétele), míg a rosszul differenciált vagy ER-t $<20 \%$-os arányban tartalmazó esetek (HG/LER) a magas rizikójú ( RS > 25) csoportba tartoznak. A fennmaradó esetek nem sorolhatók be a szabály alapján [11].

Az ismert prognosztikus és prediktív faktorok közül a stádiumot a T, N és M kategóriákon túl befolyásoló tényezők a következő formában kerültek a prognosztikai stádiumok definícióiba: a szövettani grade a nottinghami séma szerint háromosztatú változóként (I, II vagy III); az ER-, PR- és HER2-státusz pozitív vagy negatív minőségben, az Emlőrák Konszenzus Konferencia által is támogatott ajánlások szerint [12]. Opcionálisan, ha ismert, akkor az ODX-RS alacsony $(\mathrm{RS}<\mathrm{ll})$ értéke is befolyásolhatja a prognosztikai stádiumot, míg ha magasabb az értéke vagy ismeretlen, akkor nincs befolyással a stádiumra. Az így, tehát hét vagy nyolc tényező alapján képzett stádiumot prognosztikai stádiumnak, míg a csupán a T, N és M kategóriák alapján meghatározottat anatómiai stádiumnak nevezik [2]. Utóbbira többek között azért van szükség, mert a világ számos területén a prognosztikai stádiumot meghatározó tényezők nem állnak rendelkezésre. Az UICC által javasolt TNM-8 eltér az eddig ismertetett AJCC-stádiumbeosztástól, mivel csak a ha- gyományos anatómiai stádiumokat tartalmazza, amelyek majdnem teljesen azonosak az amerikai besorolással. Az európai ajánlásban a prognosztikus stádiumok, illetve a genomikai tesztek nem szerepelnek [3].

Célkitűzésünk az volt, hogy az új TNM-alapú stádiumbesorolásban figyelembe vett prognosztikus változókat, valamint az anatómiai és prognosztikai stádiumokat vizsgáljuk elhunyt, de korábban emlőrákkal diagnosztizált beteganyagunkban a teljes túlélés alapján.

\section{Anyag és módszer}

Retrospektív vizsgálatunkba a 2010 és 2015 között a kecskeméti Bács-Kiskun Megyei Oktató Kórházban mütött, reszekciós mintán alapuló kórszövettani vizsgálattal kórismézett, 2010. január 1. és 2017. január 31-ig elhunyt és a kórház Patológiai Osztályán kiállított halottvizsgálati bizonyítványú emlőrákos betegeket vontuk be. A csak biopsziás anyagból vagy metastasectomiás mintából kórismézett eseteket kizártuk a vizsgálatból, akárcsak a bilateralis emlőrákokat és az egyéb primer malignus tumorral (kivéve in situ carcinomával vagy basaliomával) kórismézett eseteket, ha daganatuk kiújult, és nem lehetett eldönteni, hogy melyik tumor metasztázisával, kiújulásával állunk szemben. Ugyancsak kizárásra kerültek azok, akiknél nem lehetett hitelt érdemlően eldönteni, hogy daganatos vagy nem daganatos volt a halálokuk.

A halálozás okait boncolás esetén a jegyzőkönyv, ennek hiányában a boncolás mellőzéséhez rendelkezésre álló klinikai adatok, valamint az utolsó klinikai zárójelentés segítségével vizsgáltuk. A halál okát illetően három kategóriát definiáltunk. A „dead of disease” (DOD) alatt azokat a betegeket értjük, akik a betegség progressziója, disszeminációja miatt hunytak el. Ezek a páciensek jelentik a tumoros halálozás csoportját. A „dead of other causes" (DOOC) kategóriájába tartoznak azok az elhunytak, akik más okok miatt haltak meg, és az emlőrák kiújulásának semmi bizonyítéka nem állt fenn náluk. Végül a „dead with disease” (DWD) csoport tagjainál az emlőrák igazolt lokális, regionális vagy távoli kiújulása mellett a halál oka a daganattól független volt (például akut myocardialis infarctus, nyelőcsővarix-ruptura vagy hosszan tartó ágyban fekvést követő masszív letalis tüdőembólia).

A prognosztikus markereink adatait a betegek kórszövettani leleteiból nyertük. A periódus elején diagnosztizált emlőrákok esetében a HER2-státusz még nem minden esetben volt rutinszerü része a szövettani leleteknek, így a prognosztikai stádiumot nem minden esetben lehetett meghatározni. ODX-vizsgálat egyik betegnél sem történt. Ahol lehetett (ER-pozitív, HER2-negatív státusz, M0 és pN0, de emellett külön, a nyirokcsomóstátusztól függetlenül is) megvizsgáltuk a Gage és mtsai által leírt ODX-helyettesítő szabályt (ODX-HSz) is [11], az ez alapján való besorolást azonban nem vettük figyelembe a prognosztikai stádium meghatározásakor. 
1. táblázat |A betegek főbb klinikai jellemzői

\begin{tabular}{|c|c|c|c|}
\hline Változó & & $\mathrm{n}$ & $\%$ \\
\hline \multirow[t]{6}{*}{ Kor } & 29-39 év & 11 & 3,6 \\
\hline & 40-49 év & 40 & 13,3 \\
\hline & $50-59$ év & 66 & 21,8 \\
\hline & 60-69 év & 76 & 25 \\
\hline & 70-79 év & 82 & 27 \\
\hline & 80-91 év & 28 & 9,3 \\
\hline \multirow[t]{2}{*}{ Oldal $^{*}$} & Jobb & 141 & 46,5 \\
\hline & Bal & 161 & 53,5 \\
\hline \multirow[t]{3}{*}{ Reszekció típusa } & Ablatio & 132 & 43,5 \\
\hline & Reszekció & 171 & 56,5 \\
\hline & $A B D$ vagy $S L N B$ & 294 & 97 \\
\hline \multirow[t]{5}{*}{ Tumortípus } & NST & 231 & 76,2 \\
\hline & ILC & 40 & 13,2 \\
\hline & Kevert & 9 & 3 \\
\hline & Mucinosus & 8 & 2,6 \\
\hline & Egyéb & 15 & 5 \\
\hline \multirow[t]{4}{*}{ Halál oka } & DOD & 168 & 55,4 \\
\hline & DOOD & 106 & 35 \\
\hline & DWD & 29 & 9,6 \\
\hline & & \multicolumn{2}{|c|}{ hónap } \\
\hline \multirow[t]{3}{*}{ OS-medián } & DOD & \multicolumn{2}{|c|}{36} \\
\hline & DOOD & \multicolumn{2}{|c|}{64,5} \\
\hline & DWD & \multicolumn{2}{|c|}{33} \\
\hline \multirow[t]{3}{*}{ OS-minimum } & DOD & \multicolumn{2}{|c|}{0} \\
\hline & DOOD & \multicolumn{2}{|c|}{2} \\
\hline & DWD & \multicolumn{2}{|c|}{0} \\
\hline \multirow[t]{3}{*}{ OS-maximum } & DOD & \multicolumn{2}{|c|}{159} \\
\hline & DOOD & \multicolumn{2}{|c|}{179} \\
\hline & DWD & \multicolumn{2}{|c|}{178} \\
\hline
\end{tabular}

*Egy esetben retrospektíven nem lehetett az oldaliságot megállapítani.

DOD $=$ dead of disease $;$ DOOC $=$ dead of other causes $;$ DWD $=$ dead with disease - csoportok magyarázatait lásd a módszertanban; ILC = invazív lobularis emlőrák; NST = nem speciális típusú emlőrák; OS = teljes túlélés

Munkánkhoz személyes adatokra nem volt szükség, ezért az adatokat azonnal anonimizáltuk. Retrospektív, beavatkozással nem járó vizsgálatunkat a Bács-Kiskun Megyei Oktató Kórház Etikai Bizottsága és Adatvédelmi Biztosa véleményezte, és kifogást egyik sem emelt.

Statisztikai vizsgálatainkat Sigmaplot 11.0 statisztikai elemzőszofverrel (Systat Software Inc., San Jose, CA, Amerikai Egyesült Államok) végeztük. Statisztikai modelljeink az egyszempontos ANOVA, a Dunn-féle post hoc teszt, valamint Kaplan-Meier-analízis voltak, amely-
2. táblázat A morfológiai változók tumoros (DOD) és nem tumoros (DOOC/DWD) halálozással való kapcsolata

\begin{tabular}{|c|c|c|}
\hline Változó & Egyutas ANOVA & $\begin{array}{l}\text { Dunn-féle post } \\
\text { hoc test }\end{array}$ \\
\hline \multirow[t]{3}{*}{$\mathrm{pT}$} & $\mathrm{p}<0,001$ & \\
\hline & DOD vs. DOOC & $\mathrm{p}<0,05$ \\
\hline & DOD vs. DOOC/DWD & $\mathrm{p}<0,05$ \\
\hline \multirow[t]{3}{*}{$\mathrm{pN}$} & $\mathrm{p}<0,001$ & \\
\hline & DOD vs. DOOC & $\mathrm{p}<0,05$ \\
\hline & DOD vs. DOOC/DWD & $\mathrm{p}<0,05$ \\
\hline \multirow[t]{3}{*}{ Gradus } & $\mathrm{p}<0,001$ & \\
\hline & DOD vs. DOOC & $\mathrm{p}<0,05$ \\
\hline & DOD vs. DOOC/DWD & $\mathrm{p}<0,05$ \\
\hline \multirow[t]{3}{*}{ Kor } & $\mathrm{p}<0,001$ & \\
\hline & DOD vs. DOOC & $\mathrm{p}<0,05$ \\
\hline & DOD vs. DOOC/DWD & $\mathrm{p}<0,05$ \\
\hline \multirow[t]{3}{*}{ ER } & $\mathrm{p}<0,001$ & \\
\hline & DOD vs. DOOC & $\mathrm{p}<0,05$ \\
\hline & DOD vs. DOOC/DWD & $\mathrm{p}<0,05$ \\
\hline \multirow[t]{3}{*}{ PR } & $\mathrm{p}<0,001$ & \\
\hline & DOD vs. DOOC & $\mathrm{p}<0,05$ \\
\hline & DOD vs. DOOC/DWD & $\mathrm{p}<0,05$ \\
\hline \multirow[t]{3}{*}{ HER2 } & $\mathrm{p}<0,001$ & \\
\hline & DOD vs. DOOC & $\mathrm{p}<0,05$ \\
\hline & DOD vs. DOOC/DWD & $\mathrm{p}<0,05$ \\
\hline
\end{tabular}

\begin{tabular}{lll}
\hline TNBC & $\mathrm{p}<0,001$ & \\
\cline { 2 - 3 } & DOD vs. DOOC & $\mathrm{p}<0,05$ \\
\cline { 2 - 3 } & DOD vs. DOOC $/$ DWD & $\mathrm{p}<0,05$ \\
\hline
\end{tabular}

\begin{tabular}{lll}
\hline Immunprofil & \multicolumn{2}{l}{$\mathrm{p}<0,001$} \\
\cline { 2 - 3 } & DOD vs. DOOC & $\mathrm{p}<0,05$ \\
\cline { 2 - 3 } & DOD vs. DOOC $/ \mathrm{DWD}$ & $\mathrm{p}<0,05$ \\
\hline ODX-HSz & $\mathrm{p}=0,006$ & \\
\hline $\mathrm{pN0}-3$ & $\mathrm{DOD}$ vs. DOOC & $\mathrm{p}<0,05$ \\
\cline { 2 - 3 } & DOD vs. DOOC $/ \mathrm{DWD}$ & $\mathrm{p}<0,05$ \\
\hline ODX-HSz & $\mathrm{p}=0,080$ & \\
\hline $\mathrm{pN0}$ & DOD vs. DOOC & $\mathrm{NA}$ \\
\cline { 2 - 3 } & DOD vs. DOOC $/ \mathrm{DWD}$ & $\mathrm{NA}$ \\
\hline
\end{tabular}

Prognosztikai stádium $\quad \mathrm{p}<0,001$

\begin{tabular}{lll}
\cline { 2 - 3 } & \multicolumn{1}{l}{$\mathrm{DOD}$ vs. DOOC } & $\mathrm{p}<0,05$ \\
\hline & DOD vs. DOOC $/ \mathrm{DWD}$ & $\mathrm{p}<0,05$ \\
\hline Anatómiai stádium & $\mathrm{p}<0,001$ & \\
\cline { 2 - 3 } & DOD vs. DOOC & $\mathrm{p}<0,05$ \\
\hline & DOD vs. DOOC $/ D W D$ & $\mathrm{p}<0,05$
\end{tabular}

ER = ösztrogénreceptor-státusz; HER2 = humán epidermalis növekedési faktor receptor-2 státusz; NA = nincs adat; ODX-HSz = Oncotype Dx helyettesítő szabály [11]; PR = progeszteronreceptor-státusz; $\mathrm{pT}$ és $\mathrm{pN}=\mathrm{a}$ TNM által definiált kategóriák; TNBC = tripla negatív emlőrák 
3. táblázat | Prognosztikus változók ötéves teljes túlélési (OS) adatai

\begin{tabular}{|c|c|c|c|c|c|c|}
\hline Változó & & $\mathrm{n}(\mathrm{DOD})$ & $\mathrm{n}(\mathrm{DOOC})$ & $\mathrm{n}$ & OS (\%) & $\mathrm{p}(\log \text { rank })^{*}$ \\
\hline \multirow[t]{7}{*}{ pT } & Tla & 2 & 3 & 7 & 33,3 & pTlb-T3 $=0,024$ \\
\hline & Tlb & 4 & 10 & 15 & 53,8 & pTlb-T4 = 0,024 \\
\hline & Tlc & 25 & 36 & 71 & 40 & pTlc-T4 $=0,034$ \\
\hline & $\mathrm{T} 2$ & 73 & 47 & 144 & 34,6 & pT2-T4 $=0,015$ \\
\hline & $\mathrm{T} 3$ & 16 & 4 & 31 & 27,6 & \\
\hline & $\mathrm{T} 4$ & 11 & 6 & 31 & 20,7 & \\
\hline & $\mathrm{x}, 0$ & 4 & 0 & 4 & 0 & \\
\hline \multirow[t]{5}{*}{$\mathrm{pN}$} & No & 23 & 57 & 91 & 50 & $\mathrm{pN} 0-\mathrm{Nl}=0,012$ \\
\hline & $\mathrm{Nl}$ & 44 & 26 & 87 & 28,6 & $\mathrm{pN} 0-\mathrm{N} 2=0,024$ \\
\hline & $\mathrm{N} 2$ & 39 & 13 & 65 & 34,4 & $\mathrm{pN} 0-\mathrm{N} 3<0,001$ \\
\hline & N3 & 28 & 8 & 53 & 22,9 & \\
\hline & $\mathrm{Nx}$ & 1 & 2 & 7 & 32,5 & \\
\hline \multirow[t]{4}{*}{ GI-III } & GI & 5 & 24 & 37 & 45,7 & pGII-GIII $=0,014$ \\
\hline & GII & 46 & 47 & 117 & 42,3 & pGI-GIII $=0,008$ \\
\hline & GIII & 83 & 35 & 147 & 27,7 & \\
\hline & Gx & 1 & 1 & 2 & 43,5 & \\
\hline \multirow[t]{3}{*}{ ER } & $\mathrm{ER}+$ & 92 & 74 & 206 & 43,7 & $\mathrm{p}<0,001$ \\
\hline & ER- & 74 & 12 & 94 & 18,4 & \\
\hline & ERX & 2 & 0 & 3 & 28,4 & \\
\hline \multirow[t]{3}{*}{ PR } & $\mathrm{PR}+$ & 77 & 83 & 176 & 44,2 & $\mathrm{p}<0,001$ \\
\hline & PR- & 86 & 23 & 121 & 23 & \\
\hline & PRX & 5 & 0 & 6 & 35,2 & \\
\hline \multirow[t]{3}{*}{ HER2 } & HER2 + & 22 & 6 & 31 & 34,5 & \\
\hline & HER2- & 96 & 87 & 202 & 37,1 & \\
\hline & HER2X & 50 & 13 & 70 & 35,1 & \\
\hline \multirow[t]{3}{*}{ TNBC } & TNBC+ & 39 & 5 & 49 & 14,6 & $\mathrm{p}<0,001$ \\
\hline & TNBC- & 77 & 88 & 182 & 43 & \\
\hline & TNBCX & 52 & 13 & 72 & 38,5 & \\
\hline \multirow[t]{5}{*}{ Immunprofil } & 1: ER+ (HER2-) & 68 & 81 & 167 & 41,7 & $\mathrm{pl}-2=0,003$ \\
\hline & 2: HER2+ & 22 & 3 & 27 & 12,5 & \\
\hline & 3: HER2+ HR+ & 10 & 3 & 14 & 54,5 & $\mathrm{pl}-4<0,001$ \\
\hline & 4: TNBC & 39 & 5 & 49 & 14,6 & $\mathrm{p} 3-4=0,05$ \\
\hline & $\mathrm{X}$ & 23 & 14 & 46 & 35,4 & \\
\hline ODX-HSz & LG-PR+ & 1 & 5 & 8 & 44,8 & $\mathrm{p}<0,001$ \\
\hline \multirow[t]{2}{*}{ pN0-3 } & HG/LER & 13 & 3 & 17 & 27,3 & \\
\hline & $\mathrm{X}$ & 154 & 98 & 278 & 35,3 & \\
\hline ODX-HSz & LG-PR+ & 0 & 3 & 3 & 64,5 & \\
\hline \multirow[t]{2}{*}{ pNo } & HG/LER & 4 & 1 & 6 & 43,9 & \\
\hline & $\mathrm{X}$ & 24 & 53 & 82 & 52,1 & \\
\hline
\end{tabular}

*Csak a szignifikáns p-értékek szerepelnek.

$\mathrm{ER}$ = ösztrogénreceptor-státusz; GI-III = alacsony, közepes, illetve magas gradus; HER2 = humán epidermalis növekedési faktor receptor-2 státusz; HG/LER = magas gradusú vagy alacsony ER-expressziójú esetek; HR = hormonreceptor; LG-PR = alacsony gradusú és progeszteronreceptor-pozitív esetek; ODX-HSz = Oncotype Dx helyettesítő szabály $[11] ; \mathrm{PR}=$ progeszteronreceptor-státusz; $\mathrm{pT}$ és $\mathrm{pN}=$ a TNM által definiált kategóriák; TNBC = tripla negatív emlórák 
nél a csoportok közötti különbségeket log rank teszttel tanulmányoztuk. Szignifikanciaszintnek a $\mathrm{p}<0,05$ értéket választottuk.

\section{Eredmények}

A módszereknél leírt kizárások után 303 emlötumoros beteg ( 298 nő, 5 férfi) adatait tudtuk elemezni. Közülük 60-nál volt kórboncolás, a többi esetben a halál okának megállapítása klinikai adatok alapján történt. A vizsgált betegek közül 52 neoadjuváns kezelésben részesült. A beválasztási feltételek miatt mindegyiküknél fennállt residualis daganat. Az alábbiakban részletezett statisztikai vizsgálatainkat kizárásuk után is megismételtük, és mivel hasonló eredményeket kaptunk, ezért kizárásuktól eltekintettünk.

Az 1. táblázat mutatja be a betegek és tumoraik alapvető, részben klinikai, részben patológiai jellemzőit. A betegek medián életkora 64 év volt a mútét idejekor. Az emlőrák miatti múttétek közel háromnegyede a hatodik-nyolcadik évtizedben történt. Az oldaliságot illetôen eltérés nem volt. A vizsgált esetek több mint felénél emlőmegtartó reszekció történt, és a legtöbb esetben nyirokcsomókat is távolítottak el. Az elemzett tumorok között a leggyakoribb a nem speciális típusú (korábban ductalis) invazív emlöcarcinoma, majd az invazív lobularis carcinoma volt. Előfordultak még kevert, mucinosus és további ritka daganatok, mint a szolid papillaris carcinoma $(\mathrm{n}=3)$, a tubularis carcinoma $(\mathrm{n}=3)$, a mátrixtermelő $(\mathrm{n}=1)$, a medullaris jellegü $(\mathrm{n}=1)$ és a sarcomatosus emlőrák $(\mathrm{n}=1)$. A betegek kétharmadánál a halálozás összefüggésbe hozható a tumorspecifikus vagy daganatos alapbetegséggel.

$\mathrm{Az}$ egyszempontos ANOVA-modell segítségével az egyes változók tumoros halálozással való összefüggését vizsgáltuk. A Dunn-féle post hoc teszttel a tumoros (DOD) és nem tumoros halálozás (DOOC+/-DWD) közötti kapcsolatot elemeztük a vizsgált változóra nézve. Eredményeinket a 2. táblázat mutatja be. Szignifikáns különbséget találtunk a tumoros halálozás csoportja, valamint a nem tumoros halálozás csoportja között a pT és a pN kategóriák, a gradus, az ER- és a HER2-státusz, a tripla negativitás, az utóbbiakat csoportosító immunprofil (3. táblázat), az ODX-HSz, valamint a prognosztikai és anatómiai stádiumbesorolás vonatkozásában.

Kaplan-Meier-modellel becsültük az egyes változókhoz tartozó ötéves teljes túléléseket. A teljes túlélés mediánja 41 hónap, átlaga 53,3 hónap, minimális értéke 0 és maximuma 179 hónap volt. További eredményeinket a 3. táblázat mutatja be. Szignifikáns különbségeket tudtunk kimutatni a pT1b, pTlc, pT2, pT3, pT4 csoportok különböző összehasonlításai között, a pN0 és bármilyen más pN-kategória között, a II. és III., valamint az I. és III. gradus között, az ER-státusz, a tripla negativitás, valamint az immunprofil kategóriái között.

$\mathrm{Az}$ immunprofil kategóriái az onkoterápiás kezelés döntéseit meghatározó ER-, PR-, HER2-immunhiszto- kémia eredményén alapulnak. A legkedvezőbb prognózist az ER-pozitív és HER2-negatív emlőrákos esetek mutatják, nyomukban a HER2-pozitív és hormonreceptor-pozitív esetekkel. A HER2-pozitív és hormonreceptor-negatív esetek átmeneti prognózisúak, míg a tripla negatív emlőrákok a legrosszabb kórjóslatú csoportot alkotják.

Az ODX-RS-t alapvetốen a nyirokcsomóáttét nélküli ER-pozitív és HER2-negatív esetekre validálták és értelmezik. Saját anyagunkban a pN0M0 kategóriába tartozó 91 eset közül csak kevés $(\mathrm{n}=9$ ) esett az LG-PR, illetve HG/LER csoportokba, ezért az ODX-HSz elemzési tartományát kiterjesztettük minden nodalis státuszra, hiszen az ODX-RS ezen betegek esetén is prognosztikus. Így sikerült szignifikáns teljes túlélésbeli különbséget kimutatni az alacsony és magas rizikójú esetek között.

$\mathrm{Az}$ anatómiai stádiumok (1.ábra) becsült ötéves teljes túlélési adatai a következők: I. stádium: 56,2\%, II. stádium: 41,5\%, III. stádium: 32,0\%, IV. stádium: 6,1\%. Az I. és II. stádium teljes túlélési becslései nem különböznek $(\mathrm{p}=0,34)$, ellenben minden további kategória különbözik a többitôl $(\mathrm{p}<0,001)$. A prognosztikai stádiumok (2. ábra) szerint az ötéves teljes túlélési adatok az I. stádiumban: $55,8 \%$, a II. stádiumban: $50,0 \%$, a III. stádiumban: $25,5 \%$ és a IV. stádiumban: $6,1 \%$. Az I. és II. stádium a teljes túlélési adatok alapján nem különbözik $(\mathrm{p}=0,69)$, ellenben minden további stádium különbözik a többitól $(\mathrm{p}<0,001)$.

A IV. stádiumban (3. ábra) a biomarkerek használatával ötéves teljes túlélésbeli különbség mutatható ki az ER-pozitív, HER2-negatív esetek $(17,6 \%)$ és a tripla negatív emlörákok $(0 \%)$ között $(\mathrm{p}=0,044)$. A HER2-pozitív és hormonreceptor-negatív esetek $(0 \%)$, valamint a HER2-pozitív és hormonreceptor-pozitív esetek $(0 \%)$ a teljes túlélés alapján nem különböztek a többi csoporttól.

\section{Megbeszélés}

A szolid tumorok onkológiai ellátásában a TNM-alapú stádiumbesorolás több mint fél évszázada megállta a helyét. Sikerének kulcsa, hogy mindig igyekezett figyelembe venni az onkológiai gyakorlat változásait. Az elmúlt három évtizedben számos biomarker jelent meg, amelyek a hagyományos patológiai prognosztikus markerek mellett jelentősen átalakították az emlőrák kezelését és kórjóslatát.

Az AJCC nyolcadik stádiumbeosztása 2018 januárjától érvényes $[2,5]$. Az új kiadást előkészítő bizottság figyelembe vette az emlőrák biológiájáról való tudásunk folyamatos növekedését és ennek hatását a betegség kezelésére, kimenetelére. A korábbi kiadásokkal ellentétben a hagyományos $\mathrm{T}, \mathrm{N}, \mathrm{M}$ kategóriák mellett a rendszer finomítása céljából új biomarkereket ajánlottak a prognosztikus kategóriák közé. Ezáltal a „tumour burden" mellett a daganat biológiai viselkedése is jelentőséget kapott. Az új kiadás szervesen kapcsolódik a múlt 


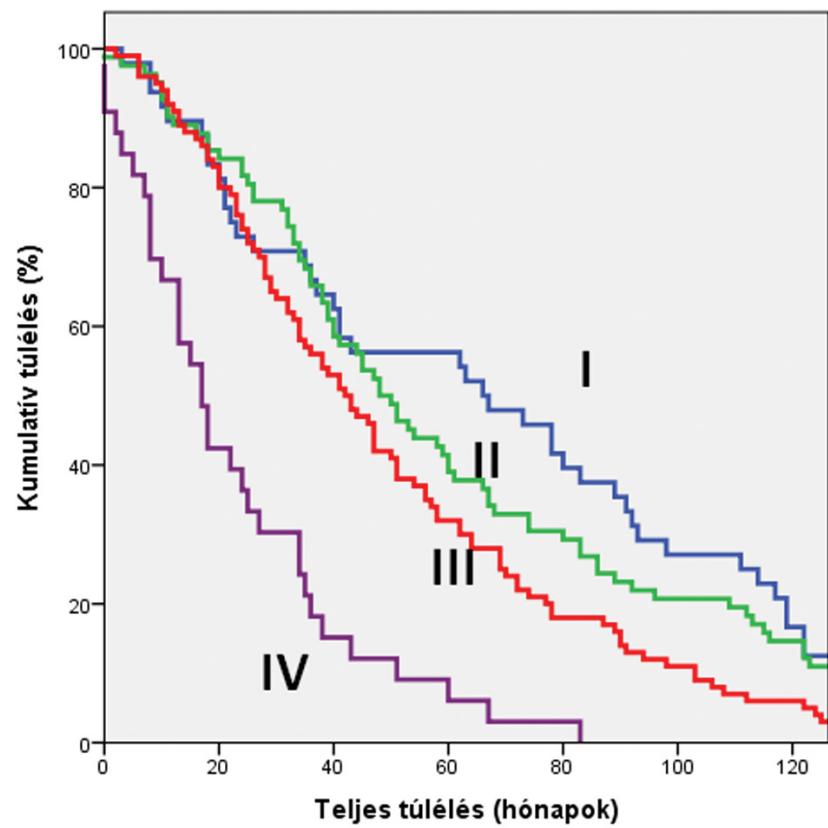

1. ábra $\quad$ Az anatómiai stádiumok Kaplan-Meier-modellel becsült ötéves teljes túlélési adatai

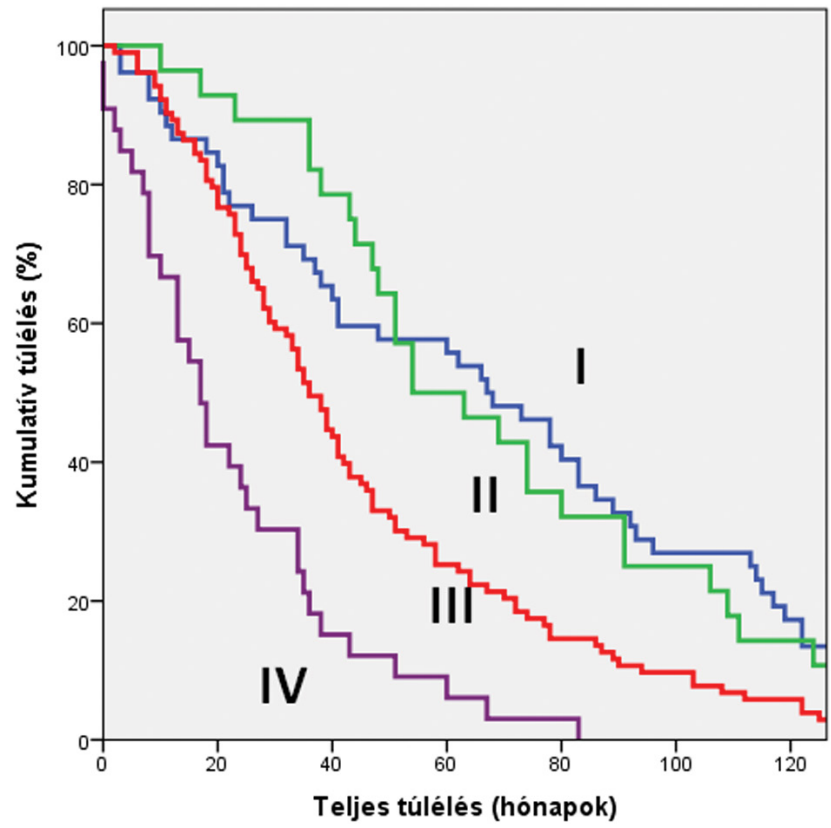

2. ábra

| A prognosztikai stádiumok Kaplan-Meier-modellje

korábbi stádiumbeosztásaihoz, mivel az új biomarkereket magába foglaló prognosztikai stádium mellett a hagyományos anatómiai stádiumbesorolást is fenntartották. Az előbbi használható azokban az országokban, ahol a biomarkerek vizsgálata rutinszerüen része a diagnosztikának, utóbbi azokban a fejlődő országokban, ahol ezek a tesztek nem elérhetőek. A helyzetet tovább komplikálja, hogy az AJCC nyolcadik stádiumbeosztásában szereplő prognosztikai stádiumokat az európai UICC nyolcadik kiadása nem vette figyelembe [3].

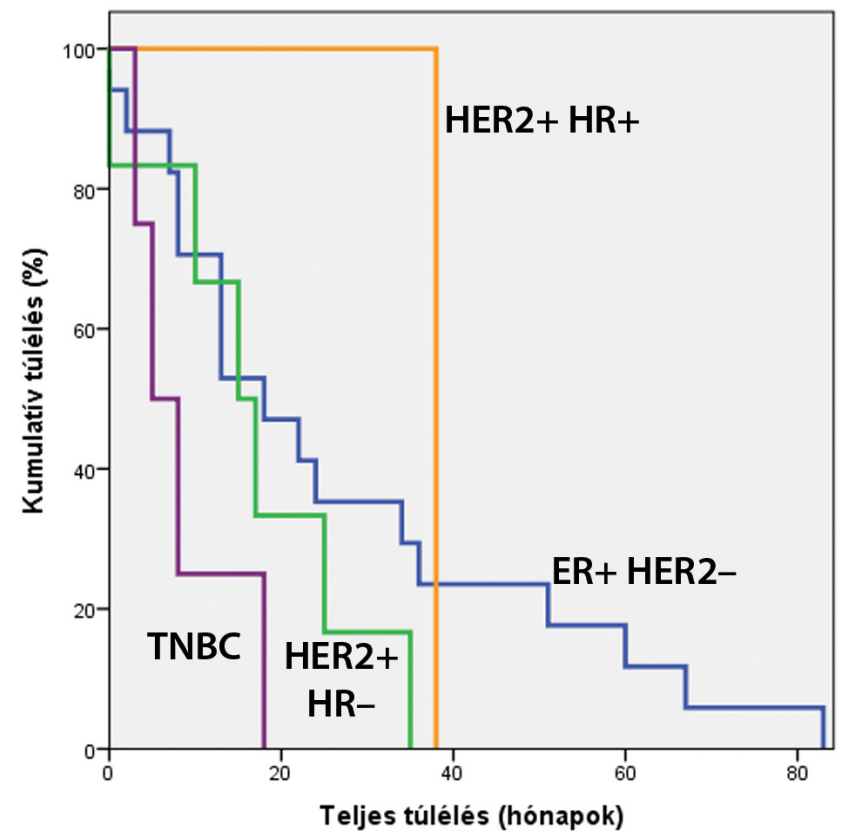

3. ábra $\begin{aligned} & \text { A IV. stádiumú betegek túlélésének alakulása az immunprofil } \\ & \text { alapján }\end{aligned}$
HER2 = humán epidermalis növekedési faktor receptor-2 stá-
tusz; HR = hormonreceptor-státusz; ER = ösztrogénreceptor-
státusz; TNBC = tripla negatív emlőrák

Az onkológiai betegek statisztikai igényeket kielégítő követése, a klinikai vizsgálatokon kívül, nem jól megoldott hazánkban. A legtöbb kezeléssel, illetve betegséggel, így az emlőrákkal kapcsolatosan sem állnak rendelkezésre betegségspecifikus, betegségmentes, illetve teljes túlélési adatok; a statisztikai adatgyưjtés a betegség gyakoriságára és mortalitására irányul. A leggyakrabban becsléssel kell megközelíteni a túlélési adatokat, és erre a Kaplan-Meier-féle modellek alkalmazása megfelelő. Jelen vizsgálatban a betegek követése nem állt rendelkezésre, haláluk kapcsán viszont, a kórbonctani diagnosztika részeként, tumorral kapcsolatos anamnézisük minden esetben részletesen feltárásra került. Így a Kaplan-Meiermodellek nem becslésen, hanem valós teljes túlélési adatokon alapultak, és a prognosztikus tényezők szerinti összehasonlításokban is valós túlélési adatokat tudtunk figyelembe venni.

Több tanulmánnyal $[13,14]$ összhangban, a szövettani grade kórjóslatot befolyásoló szerepét vizsgálatunkban megerôsítettük.

Az ER-, PR- és HER2-státusz biológiai viselkedést jellemző szerepét számos dolgozat igazolta. Erre jó példa a tripla negatív emlőtumorok esete. Kezelésük kihívást jelent, és prognózisuk a legkedvezőtlenebb [8-10, 15]. A szakirodalmi adatokkal összhangban a tripla negatív emlőrákos betegek teljes túlélése volt a legrosszabb - betegeink közül is alig több mint egynegyedük élt öt éven túl. Nyomukban a HER2-pozitív és hormonreceptornegatív esetek álltak. A teljes túlélés alapján a spektrum kedvezőbb végén az ER-pozitív és HER2-negatív esete- 
ket találtuk. Mint tudjuk, ezt a csoportot is két részre szokás manapság bontani, mint luminális „A”-szerü és luminális „B”-szerü daganatokat [12], de vizsgálatunkban a két eltéró prognózisú csoportot nem állt módunkban elkülöníteni.

A HER2 expresszióját eredetileg kedvezőtlen prognosztikus markerként írták le [16], azonban a receptor ellen kifejlesztett monoklonális antitest terápiás alkalmazásával a HER2-pozitív esetek kedvezőbb kórjóslatúakká váltak [17], és ez magyarázza, hogy a prognosztikai stádiumuk az anatómiainál alacsonyabb. Anyagunkban a 31 HER2-pozitív beteg túlélése némileg rosszabb volt, mint a HER2-negatív vagy az ismeretlen HER2-státuszú betegeké (3. táblázat). Ennek tisztázására próbáltuk figyelembe venni a HER2-ellenes kezelések alkalmazását is, de ebben nem találtuk meg a HER2-pozitivitás megtartott adverz jellegének magyarázatát, ugyanis az itt be nem mutatott elemzés értelmében a kevés beteg $(\mathrm{n}=$ 14), aki nem részesült anti-HER2 célzott kezelésben, némileg jobb túlélési adatokat mutatott, mint a kezelt betegek, amit az adatok kis száma magyarázhat.

A génexpressziósprofil-alapú vizsgálatok célja a biológiai viselkedést meghatározó gének elemzése révén a recidíva jóslása. Az Egyesült Államokban az ODX a leggyakrabban használt genomikus panel [18], és eddig ez érte el az I. szintú evidenciát [19-24]. Kereskedelmi forgalomban elérhető hasonló vizsgálat a 70 gént figyelembe vevő MammaPrint $[25,26]$, továbbá az EndoPredict, a PAM 50 és a Breast Cancer Index. Egyelőre a TNM staging nyolcadik kiadásában csak az ODX-RS kapott szerepet a stádium meghatározásában. Használata opcionális, és csak a Tl-2, N0, ER-pozitív, HER2-negatív esetek „downstaging”-jében kap szerepet. Így ezen betegek IA stádiumba átsorolhatók, továbbá elkerülhetik a szisztémás kemoterápiát, ha az ODX-RS $<11$ [19-22, 25]. A molekuláris vizsgálatok hátránya a drágaságuk: az Egyesült Államokban az emlőrákos betegek harmadánál, Európában kevesebb mint 20\%-uknál végeztek ODXvizsgálatot $[18,27]$. Számos tanulmány foglalkozik azzal, hogy a drága molekuláris vizsgálat helyett olyan predikciós modellt dolgozzon ki, amellyel meg lehet jósolni az ODX-RS értéket [11, 18]. Azonban ezek a metodikák a stádiumbesorolásban természetesen nem hasznosíthatók, terápiás döntéseket pillanatnyilag, tudomásunk szerint, nem befolyásolnak. A Gage és mtsai [11] által alkalmazott ODX-HSz használatakor szignifikáns különbséget észleltünk az alacsony és a magas rizikójú betegek teljes túlélése között, ha vizsgálati tartományunkat valamennyi nodalis státuszra kiterjesztettük. A prognosztikai stádiumbesorolás során az ODX-HSz-t nem vettük figyelembe.

Vizsgálatunknak vannak korlátai. Az esetszám ugyan lehetővé tesz statisztikai összehasonlításokat, de messze elmarad a nagy népességalapú statisztikák lehetőségeitől. Az esetszámból adódó fenntartások miatt primer szisztémás kezelésben részesült eseteket is figyelembe vettünk, bár előzetesen megvizsgáltuk, hogy nélkülük változná- nak-e az eredmények. A betegadatok egy része hiányos volt, így a HER2-státusz sem állt minden beteg esetén rendelkezésre, nem is beszélve az ODX-RS-ről. Ugyanakkor némi erősséget is fel lehet ezekkel szemben sorolni. Valós túlélési adatokkal dolgoztunk. Az adatok validitását tükrözi az, hogy a prognosztikus tényezők szerint csoportosított betegek túlélése az irodalmi adatokkal összhangban áll. Ez alól kivétel, hogy a HER2-pozitív betegek túlélésének növekedése elmaradt a célzott kezelések ellenére, valamint az, hogy a prognosztikai és anatómiai stádiumok szerinti túlélésbeli tagolódás nem mutatkozott a korai stádiumok esetén. Külön figyelmet fordítottunk az anatómiai stádium és az új prognosztikai stádium kórjósló szerepére is. Eredményeink alapján az anatómiai és a prognosztikai stádiumok többsége egymástól független prognosztikus csoportot alkotott, kivéve az I. és II. stádiumokat, amelyeknek az ötéves teljes túlélése nem mutatott eltérést. Itt nem részletezett kiegészítő vizsgálatunkban külön elemeztük az anatómiai és prognosztikai I. és II. stádiumok (IA, IB, IIA, IIB) alcsoportjait, de a teljes túlélés alapján nem találtunk elkülönülő alcsoportokat. Ennek hátterében az egyes alcsoportok alacsony esetszáma állhat.

Annak ellenére, hogy a szakmai gyakorlatban ismeretesek kedvezőbb biológiai viselkedésü, hosszú túlélésű IV. stádiumú emlőrákos betegek [28], az új TNM-rendszer nem tesz különbséget biomarkerek szerint a távoli áttétes betegek stádiumai között, azaz minden Ml kategóriájú beteg IV. stádiumú, az anatómiai és prognosztikai stádiumok ebben a betegcsoportban egybeesnek. A IV. stádium esetei között, biomarkerek (immunprofil) használatával, egyes alcsoportok között sikerült szignifikáns túlélésbeli különbséget igazolnunk. Az ER-pozitív, HER2-negatív esetek túlélése jobb volt, mint a tripla negatív emlőrákos betegeké, ami új eredményként azt jelzi, hogy a IV. stádiumú betegek tagolása is megvalósítandó feladat.

Vizsgálatunkban egy hazai centrum post mortem beteganyagán retrospektív módon elemeztük a 2018-ban bevezetendő nyolcadik AJCC-stádiumbesorolást. Teljes túlélési eredményeink alapján validáltuk a hagyományos anatómiai és a biomarkereket figyelembe vevő prognosztikai stádiumbesorolást. Az I. és II. stádiumok közötti különbség, esetleg az ODX-HSz prognosztikus szerepének validálásához további, nagyobb esetszámú vizsgálatok szükségesek.

Anyagi támogatás: A közlemény megírása, illetve a kapcsolódó kutatómunka a Nemzeti Kutatási Fejlesztési és Innovációs Hivatal támogatásával történt(GINOP-2.3.215-2016-00020).

Szerzői munkamegosztás: Z. T.: Koncepció, modellezés, adatelemzés, a kézirat első változatának megszövegezése, végleges formába öntése, jóváhagyása. L. L.: Modellezés, adatok előzetes elemzése, a kézirat végleges válto- 
zatának jóváhagyása. Cs. B.: Adatkezelés, adatkonverzió, a kézirat végleges változatának jóváhagyása. Ny. T.: Statisztikai útmutatás, a kézirat végleges formájának kialakítása, végleges változatának jóváhagyása. Cs. G.: Koncepció, adatgyújtés, modellezés, részfolyamatok felügyelete, a kézirat első változatának megszövegezése, végleges formába öntése, jóváhagyása.

Érdekeltségek: A szerzőknek nincsenek érdekeltségeik.

\section{Köszönetnyilvánítás}

Köszönetünket fejezzük ki Dezső Mibálynak és Dr. Nagy Bencének a munkánk során nyújtott segítségükért.

\section{Irodalom}

[1] Amin MB, Greene FL, Edge SB, et al. The Eighth Edition AJCC Cancer Staging Manual: Continuing to build a bridge from a population-based to a more "personalized" approach to cancer staging. CA Cancer J Clin. 2017; 67: 93-99.

[2] Hortobagyi G, Connolly JL, D’Orsi CJ, et al. Breast. In: Amin MB, Edge SB, Greene FL, et al. (eds.) AJCC Cancer Staging Manual. 8th ed. Springer, New York, 2017; pp. 587-628.

[3] Brierley JD, Gospodarowicz MK, Wittekind C. (eds) UICC TNM classification of malignant tumours. 8th ed. Wiley-Blackwell, Chichester, 2016.

[4] Cserni G, Kulka J. The novel TNM classification of breast cancer [Az emlőrákok új TNM-klasszifikációja.] Orv Hetil. 2003; 144: 1563-1568. [Hungarian]

[5] 8th Edition Implementation Project. Available from: https:// cancerstaging.org/8thEdImplementation/Pages/default.aspx [accessed: June 6, 2017].

[6] Elston CW, Ellis IO. Pathological prognostic factors in breast cancer. I. The value of histological grade in breast cancer: experience from a large study with long-term follow-up. Histopathology 1991; 19: 403-410.

[7] Elston EW, Ellis IO. Method for grading breast cancer. J Clin Pathol. 1993; 46: 189-190.

[8] Giuliano AE, Connolly JL, Edge SB, et al. Breast Cancer-Major changes in the American Joint Committee on Cancer eighth edition Cancer staging manual. CA Cancer J Clin. 2017; 67: 290303.

[9] Yi M, Mittendorf EA, Cormier JN, et al. Novel staging system for predicting disease-specific survival in patients with breast cancer treated with surgery as the first intervention: time to modify the current American Joint Committee on Cancer staging system. J Clin Oncol. 2011; 29: 4654-4661.

[10] Bagaria SP, Ray PS, Sim MS, et al. Personalizing breast cancer staging by the inclusion of ER, PR, and HER2. JAMA Surg. 2014; 149: 125-129.

[11] Gage MM, Rosman M, Mylander WC, et al. A validated model for identifying patients unlikely to benefit from the 21 -gene recurrence score assay. Clin Breast Cancer 2015; 15: 467-472.

[12] Cserni G, Kulka J, Francz M, et al. Pathological diagnosis, workup and reporting of breast cancer. Recommendations of the 3rd Hungarian Consensus Conference on Breast Cancer. [Az emlőrák patológiai diagnosztikája, feldolgozása és kórszövettani leletezése. Szakmai útmutatás a III. Emlőrák Konszenzus Konferencia alapján.] Magyar Onkol. 2016; 60: 209-228. [Hungarian]

[13] Galea MH, Blamey RW, Elston CE, et al. The Nottingham Prognostic Index in primary breast cancer. Breast Cancer Res Treat. 1992; 22: 207-219
[14] Todd JH, Dowle C, Williams MR, et al. Confirmation of a prog nostic index in primary breast cancer. Br J Cancer 1987; 56: 489-492.

[15] Abdel-Rahman O. Assessment of the prognostic and discriminating value of the novel bioscore system for breast cancer; a SEER database analysis. Breast Cancer Res Treat. 2017; 164: 231-236.

[16] Slamon DJ, Clark GM, Wong SG, et al. Human breast cancer: correlation of relapse and survival with amplification of the HER-2/neu oncogene. Science 1987; 235: 177-182.

[17] Slamon DJ, Leyland-Jones B, Shak S, et al. Use of chemotherapy plus a monoclonal antibody against HER2 for metastatic breast cancer that overexpresses HER2. N Engl J Med. 2001; 344: 783-792.

[18] Orucevic A, Bell JL, McNabb AP, et al. Oncotype DX breast cancer recurrence score can be predicted with a novel nomogram using clinicopathologic data. Breast Cancer Res Treat. 2017; 163: 51-61.

[19] Sparano JA, Gray RJ, Makower DF, et al. Prospective validation of a 21-gene expression assay in breast cancer. N Engl J Med. 2015; 373: 2005-2014.

[20] Stemmer SM, Steiner M, Rizel S, et al. Real-life analysis evaluating $1594 \mathrm{~N} 0 / \mathrm{Nmic}$ breast cancer patients for whom treatment decisions incorporated the 21-gene recurrence score result: 5 -year KM estimate for breast cancer-specific survival with recurrence score results $\leq 30$ is $>98 \%$. Paper presented at: Breast Cancer Symposium. San Antonio, TX, USA, 2015.

[21] Stemmer S, Steiner M, Rizel S, et al. First prospective outcome data in 930 patients with more than 5 -year median follow up in whom treatment decisions in clinical practice have been made incorporating the 2l-gene recurrence score. Paper presented at: European Cancer Congress. Vienna, Austria, 2015.

[22] Shak S, Petkov VI, Miller DP, et al. Breast cancer-specific survival in 38,568 patients with node negative hormone receptor positive invasive breast cancer and Oncotype DX recurrence score results in the SEER database. Paper presented at: Breast Cancer Symposium. San Antonio, TX, USA, 2015.

[23] Gluz O, Nitz UA, Christgen M, et al. West German Study Group phase III PlanB Trial: first prospective outcome data for the 21gene recurrence score assay and concordance of prognostic markers by central and local pathology assessment. J Clin Oncol. 2016; 34: 2341-2349.

[24] Paik S, Shak S, Tang G, et al. A multigene assay to predict recurrence of tamoxifen-treated, node-negative breast cancer. N Engl J Med. 2004; 351: 2817-2826.

[25] Drukker CA, Bueno-de-Mesquita JM, Retèl VP, et al. A prospective evaluation of a breast cancer prognosis signature in the observational RASTER study. Int J Cancer 2013; 133: 929-936.

[26] Drukker CA, Nijenhuis MV, Bueno-de-Mesquita JM, et al. Optimized outcome prediction in breast cancer by combining the 70 -gene signature with clinical risk prediction algorithms. Breast Cancer Res Treat. 2014; 145: 697-705.

[27] Albanell J, Svedman C, Gligorov J, et al. Pooled analysis of prospective European studies assessing the impact of using the 21gene Recurrence Score assay on clinical decision making in women with oestrogen receptor-positive, human epidermal growth factor receptor 2-negative early-stage breast cancer. Eur J Cancer 2016; 66: 104-113.

[28] Tai P, Yu E, Vinh-Hung V, et al. Survival of patients with metastatic breast cancer: twenty-year data from two SEER registries. BMC Cancer 2004; 4: 60 .

(Zombori Tamás dr., Szeged, Állomás u. 1., 6725 e-mail: zomtam@gmail.com) 